\title{
Interdisciplinary Approach in Development and Implementation of Local Guideline for Surgical Antimicrobial Prophylaxis: Experience of the University Hospital "Tsaritsa Yoanna - ISUL", Sofia, Bulgaria
}

\author{
Andrey Petrov ${ }^{1}$, Emil Gatchev', Damyan Damyanov², \\ Boyko Korukov ${ }^{2}$ Emil Kolev ${ }^{1}$ \\ ${ }^{1}$ Medical University of Sofia, Department of Clinical Pharmacology and Therapeutics, \\ University Hospital “Tsaritsa Yoanna - ISUL”, Sofia, Bulgaria; \\ ${ }^{2}$ Medical University of Sofia, Gastroenterology Clinical Center, Surgery Clinic, \\ University Hospital “Tsaritsa Yoanna - ISUL”, Sofia, Bulgaria
}

\section{SUMMARY}

Objective Surgical antimicrobial prophylaxis (SAP) is a method proved to be effective in reducing the risk of surgical site infections (SSI). Although there are numerous international and local Guidelines, SAP is often performed inappropriately. The monitoring that was carried out at the Surgery Clinic of the University Hospital "Tsaritsa Yoanna - ISUL" in August 2008 showed a high level of inappropriately performed SAP. In order to optimize SAP, a Local Guideline (LG) for SAP was developed.

Methods LG for SAP was developed and implemented using the interdisciplinary approach, on the basis of internationally accepted standards of SAP, taking into account the specifics of the hospital. Monthly monitoring of the level of compliance of SAP with the LG for SAP was carried out. The use of antimicrobial agents (AMA) at the Clinic was reported using the $\mathrm{DDD} / 100$ patient day method.

Results Three months after the LG implementation, the rate of appropriately performed SAP increased from $5 \%$ to $40 \%$ and at the end of 2009 even to $92 \%$. The AMA usage in 2009 was reduced by nearly $26 \%$ : from total of $58.71 \mathrm{DDD} / 100$ patient days in 2008 to $43.45 \mathrm{DDD} / 100$ patient days and total AMA costs were reduced by more than 31\%: from $€ 29.764$ in 2008 to $€ 20.300$ in 2009 .

Conclusions The interdisciplinary approach in the development and implementation of LG for SAP led to SAP optimization at the Surgery Clinic, significant reduction in AMA usage and considerable savings of financial resources.

Keywords: antibiotics; surgery 


\section{INTRODUCTION}

SSI are an important cause of morbidity and mortality and are associated with the increased costs to health care providers [1-4]. According to the Centers for Disease Control and Prevention (CDC), SSI accounted for about $31 \%$ of nosocomial infections in the United States in 2010 [5]. An overall incidence of SSI for the intra-abdominal infections ranges from $10 \%$ to $18 \%$ [ 6 , 7]. It is widely known fact, however, that AMAs are administered inappropriately in as much as $50 \%$ of cases [8]. Errors in antimicrobial prophylaxis for surgical patients remain one of the most frequent types of preventable medication errors in hospitals [9].

The foundations of modern SAP in surgical practice were set in 1960s and 1970s by Burke [10], Polk and Lopez-Mayor [11] and Stone et al. [12]. Irrespective of the great number of international, national and local consensuses, guidelines and published articles [1318], SAP is still inappropriately performed in not a small percentage of the cases $[19,20]$. It has been found that direct implementation of "foreign" guidelines is relatively low effective mainly because of the insufficient compliance by the medical staff. A multicenter study in the Netherlands has found out that an overall adherence to the respective guidelines is $28 \%$ and the compliance regarding key parameters of SAP ranges from $43 \%$ to $92 \%$ [21]. Similar results have been seen in the assessment of SAP in Turkey [22]. In this context, it is important to identify and address the factors leading to low compliance which most often are [23]:

- Insufficient awareness of physicians related to the principles of rational prophylaxis and the comparative efficiency of the individual AMA;

- No introduced restrictive measures as regards the prescription of AMA as well as no ongoing monitoring of AMA use;

- Disagreement by the medical staff with specific aspects of the respective guidelines;

- No incentives to the medical staff;

- Influence by the pharmaceutical industry.

In August 2008, a monitoring was carried out at the Surgery Clinic of the University Hospital "Tsaritsa Yoanna - ISUL" that showed a high level of inappropriately performed SAP. The main problems in this regard were found to be as follows:
- start of AMA administration for the purposes of SAP - more than 24 hours prior to or after the end of surgical intervention;

- length of AMA administration - usually more than 72 hours and often until patients are discharged from the Clinic;

- irrational selection of AMA.

In practice, regardless of the instructions about the performance of SAP available at the Hospital, they were not followed and remained on paper only. In order to address this problem in September 2008 using an interdisciplinary approach with the leading role of clinical pharmacologists and active involvement of the Management of the Surgery Clinic, a LG for SAP was developed and implemented. The aim was an upgrading of the level of appropriate performance of SAP to the extent complying with the world standards and consequent cost savings for the Surgery Clinic as well.

\section{METHODS}

The Surgery Clinic of the University Hospital "Tsaritsa Yoanna - ISUL" is a general surgery clinic with 30 beds with prevailing abdominal pathology. LG for SAP was developed on the basis of internationally accepted standards for SAP, including motivated selection of AMA, route, time, and length of administration [1318]. In developing the LG for SAP the specifics of the Hospital were also considered such as:

- prevailing surgical interventions at the Clinic;

- local antibiotic resistance;

- drug list of the Hospital;

- considerations of the Surgery Clinic Management as regards the manner of performance of SAP based on their longtime experience;

- financial capacity of the Hospital.

Surgical interventions where the performance of SAP is mandatory (e.g., hemicolectomy, appendectomy, etc.) as well as surgeries where SAP is not to be performed (e.g., herniotomy without mesh insertion) were specified in the LG. Selecting an AMA (or a combination of AMA) for the purposes of SAP was based on the following requirements:

- AMA must have a spectrum consistent with the most common causes of SSI in the specific surgical interventions; 
- AMA are to be administered in the manner ensuring high plasma and tissue concentrations exceeding $\mathrm{MIC}_{90}$ for the potential pathogen from the incision until the end of surgical intervention;

- AMA must have favorable profile of adverse drug reactions;

- AMA are to be cost-effective.

In the prevailing part of surgical interventions, LG provides preoperative (30-60 minutes prior to the surgical intervention) intravenous administration of a single dose of the respective AMA. According to LG, the second dose of AMA should be administered when there are extra risk factors such as: surgery duration $>3$ hours, blood loss $>1.5 \mathrm{~L}$, infusion of fluids $>15 \mathrm{~mL} / \mathrm{kg} /$ weight as well as in development of intra-operative complications. In strictly specified surgical interventions (e.g., gastric, colon, or extra-hepatic bile duct cancer) in high-risk patients, LG allows for extension of SAP length for up to 48 hours in the discretion of the surgical team.

Four approaches such as training, restriction, monitoring, and feedback were used in the implementation of LG into the clinical practice.

The training of the medical staff at the Surgery Clinic was carried out by clinical pharmacologists in the form of lectures, seminars and discussions. The aim was to update the surgical teams on the set goals, the expected results as well as direct benefits both for the patients (increased efficacy and safety) and the hospital (improvement of medical care to patients and saving resources).

The restriction was performed by introduction of strict rules of prescribing AMA for the purposes of SAP. In addition, the clinical pharmacologists carried out monitoring of the promotional activities of pharmaceutical companies at the Surgery Clinic in order to limit the use of cost-ineffective AMA.

The monitoring of SAP was performed by clinical pharmacologists through the monthly retrospective review of the medical records of patients that have undergone surgery at the Clinic during the respective month. For that purpose, the specific SAP checklists were designed allowing quick and accurate assessment of SAP performed on the basis of the following criteria:

- accuracy of medical records concerning SAP performed;

- presence of indications to perform SAP according to LG;
- appropriateness of AMA selection;

- exact time and route of administration of AMA relative to the start of the surgical intervention;

- length of AMA administration.

On the basis of these criteria, SAP was assessed as good, satisfactory, or not good using the three-level scale. Good grade was given when all criteria of LG were satisfied: administration of SAP when indicated, adequate AMA selection administered in an appropriate dose, dose regimen and length of administration as well as when the medical records were appropriately completed. Satisfactory grade was awarded when there were minor deviations from LG: e.g., prescribing suboptimal AMA, administration of additional and unnecessary AMA doses according to LG within up to 48 hours, as well as some omissions in the medical records. Not good grade was awarded when AMA was inappropriately selected, when AMA was administered for the purpose of prophylaxis without reason or when no AMA were administered for the purpose of prophylaxis when there were indications for such administration, when the length of SAP was more than 48 hours as well as for major omissions in the medical records. The ratio between appropriately and inappropriately performed SAP was calculated from the ratio of the sum of good and satisfactory grades and the sum of not good grades.

The feedback to the Surgery Clinic Management assumed written reports of the clinical pharmacologists at monthly intervals about the results of the completed monitoring.

The assessment of AMA usage was performed using the defined daily dose method: (DDD/100 patient days) which is an appropriate statistical measure of total drug use in a hospital [24]. Annual AMA costs were reported for the three-year period (2008-2010). For that purpose, the computerized database of the hospital pharmacy and the results from the hospital statistical unit about the number of beds at the Surgery Clinic and their average yearly occupancy were used and the calculations were performed by means of ABC Calc Version 3.1 [25].

\section{RESULTS}

The results of this study covered a three-year period of assessment of SAP and AMA use at the Surgery Clinic. Three months after the imple- 
mentation of LG for SAP, the level of appropriately performed SAP increased from $5 \%$ to $40 \%$. The upward trend continued with some fluctuations during the subsequent months as well: at month 8,12 , and 16 of the LG implementation, the level of rationally performed SAP increased o $64 \%, 79 \%$, and $92 \%$, respectively.

Table 1 shows the results of 4 monitorings of SAP carried out at the Surgery Clinic within 16 months of the implementation of LG for SAP.

The increased level of rational performance of SAP was also accompanied by considerable reduction in AMA usage at the Clinic presented through the $\mathrm{DDD} / 100$ patient day parameter. The total AMA usage was reduced by $26 \%$ in 2009 compared to 2008 , i.e. from 58.71

Table 1. Summarized results of monitoring carried out to assess the appropriateness of SAP performed at the Surge-ry Clinic of the University Hospital “Tsaritsa Yoanna - ISUL" for the period from November 2008 to December 2009

\begin{tabular}{|l|c|c|c|}
\hline \multirow{2}{*}{ Month/Year } & \multicolumn{3}{|c|}{$\begin{array}{c}\text { Assessment of appropriateness } \\
\text { of performed SAP (\%) }\end{array}$} \\
\hline November 2008 & Good & Satisfactory & Not good \\
\hline April 2009 & 24 & 16 & 60 \\
August 2009 & 36 & 28 & 36 \\
December 2009 & 58 & 21 & 21 \\
\hline
\end{tabular}

$\mathrm{DDD} / 100$ patient days to $43.5 \mathrm{DDD} / 100$ patient days. Inappropriate use of certain AMA in the period before the implementation of LG for SAP was significantly reduced, e.g., the usage of Ceftriaxone, Metronidazole, and Ciprofloxacin in 2008 compared to 2009 dropped down from 32.77 DDD/100 patient days to 25.35 DDD/100 patient days; from $15.92 \mathrm{DDD} / 100$ patient days to $10.12 \mathrm{DDD} / 100$ patient days and from 2.76 $\mathrm{DDD} / 100$ patient days to $1.73 \mathrm{DDD} / 100$ patient days, respectively. In practice, the total AMA use in 2010 was identical to that in 2009.

Table 2 shows the summarized results of the study of AMA use for the period 2008-2010.

AMA costs at the Surgery Clinic were reduced by more than $31 \%$ in 2009 compared to 2008 and further by nearly $24 \%$ in 2010 compared to 2009.

Graph 1 shows summarized data about funds for the provision of AMAs for the period 2008-2010.

\section{DISCUSSION}

SAP is a method proved to be effective in reducing the risk of SSI. It is known, however, that

Table 2. AMA use at the Surgery Clinic of the University Hospital “Tsaritsa Yoanna - ISUL” in 2008, 2009 and 2010, presented in DDD/100 patient (pt) days (calculated)

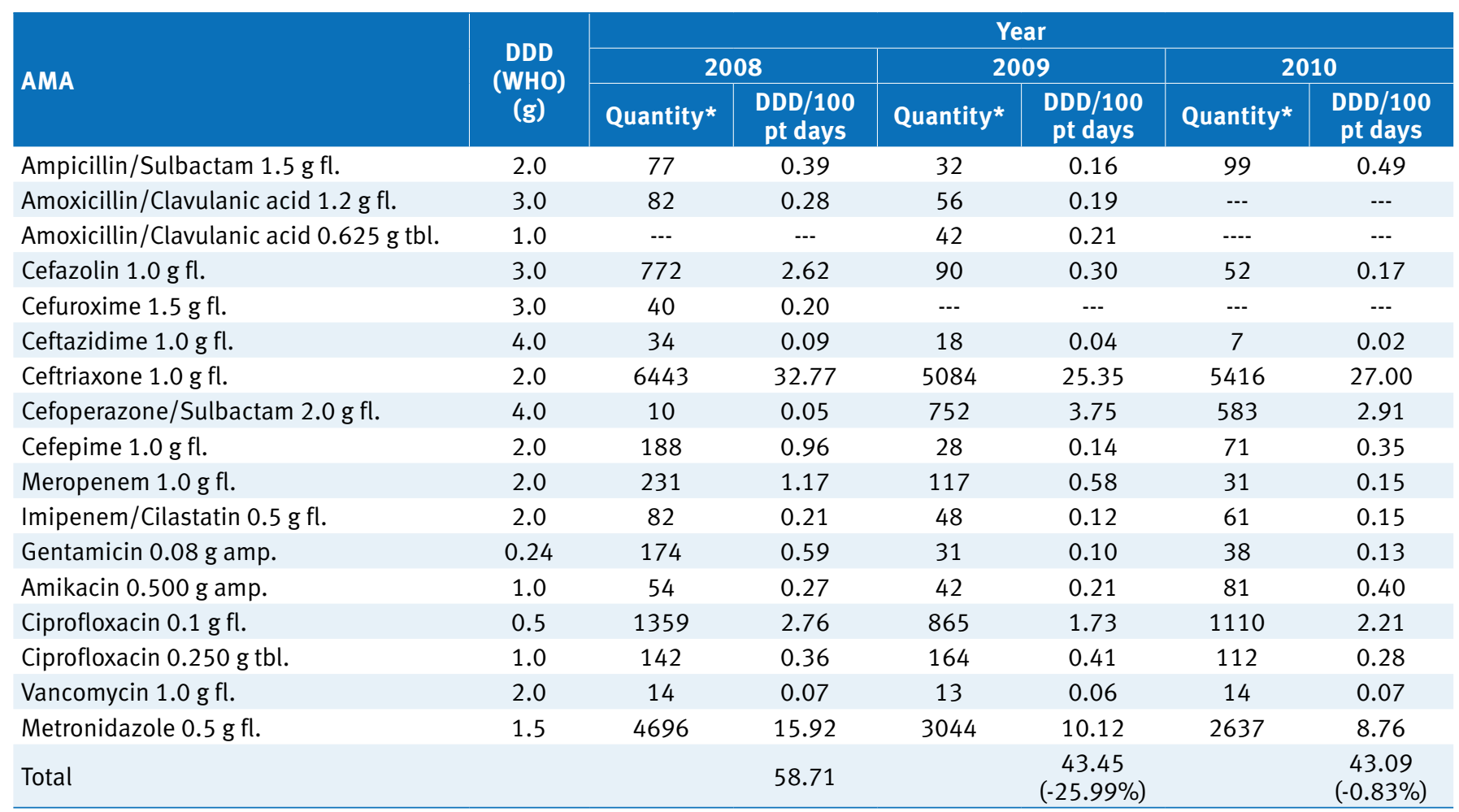

\footnotetext{
* the unit quantity of the respective AMA
} 
numerous international guidelines for the SAP are not a guarantee to their optimal implementation in the clinical practice. The development and successful implementation of LG for SAP at the Surgery Clinic of University Hospital "Tsaritsa Yoanna - ISUL" led to significant improvement of the level of appropriately performed SAP which, in our opinion, was mainly due to the following factors:

- An interdisciplinary approach was used combining the knowledge of the clinical pharmacologists about the principles of rational AMA therapy on one hand, and on the other, the longtime clinical experience of the surgical team.

- The specifics of the medical institution such as prevailing type of the surgical interventions and local level of microbial resistance to AMAs, the specifics of the drug list of the Hospital, the experience of the surgical team and, last but not the least, the financial capacity of the Hospital were considered;

- The SAP monitoring performed at monthly intervals enabled timely detection of the problems in the performance of SAP and identification of the respective measures for their correction;

- Active support by the Hospital Management as well as full cooperation by the Management of the Surgery Clinic were provided;

- Cooperative relations were established among the clinical pharmacologists and the surgeons, what further contributed to increasing compliance of surgeons.

As the result of comprehensive measures taken at the end of 2009, SAP was rationally performed in more than $90 \%$ and by this parameter the Surgery Clinic ranked among the world leading surgery clinics. The rational performance of SAP was associated with the significant reduction in AMA usage in 2009 compared to 2008, which in turn led to direct economic benefits - there was a considerable saving of financial resources as well.

Upon development and implementation of LG for SAP, some weaknesses such as the use of third-generation cephalosporins have still maintained relatively high and the acceptable length of SAP up to 48 hours in high-risk patients have not been fully resolved yet. In addition, merging the good and satisfactory grades could be also seen as a compromise in the

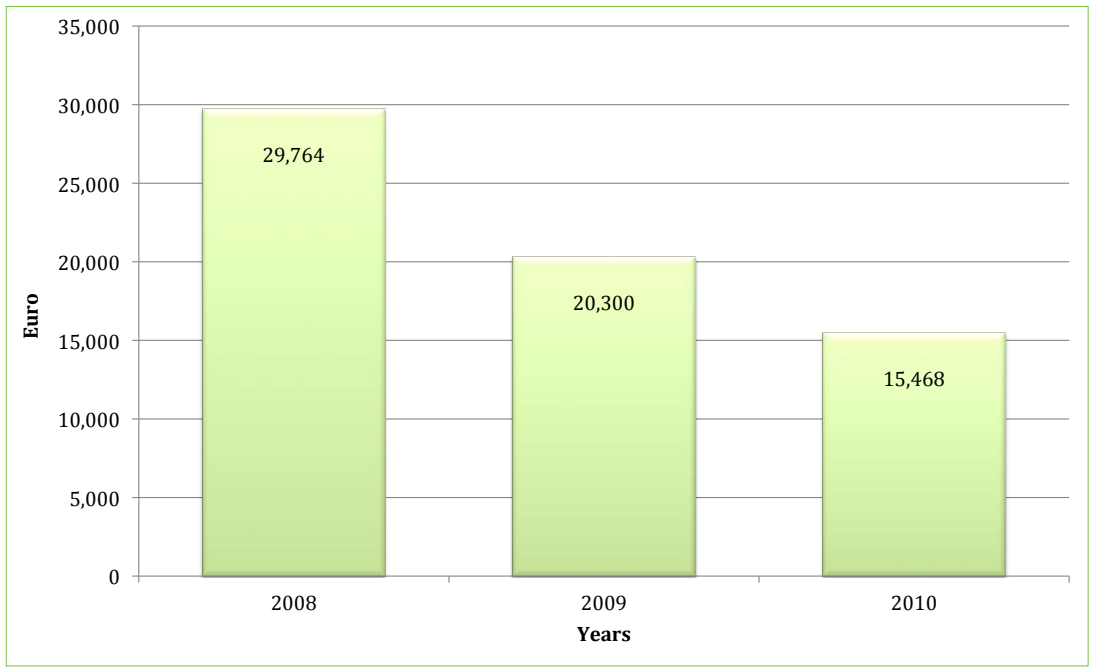

Graph 1. Annual AMA costs at the Surgery Clinic of the University Hospital "Tsaritsa Yoanna ISUL" in 2008, 2009 and 2010

assessment of the appropriateness of performed SAP. This was done mainly to avoid excessively rigid approach in SAP assessment as well as to encourage the compliance of the surgical team. A similar approach in SAP assessment has been also adopted by other authors [26].

This study is a pilot project carried out by the University Surgery Clinic in Sofia and does not claim to be exhaustive. Regardless of the joint efforts made by the clinical pharmacologists and the Management of the Surgery Clinic, it took more than one year of the implementation of LG for SAP before achieving an optimal result. In our opinion, this was due to some initial underestimation of the problem with the rational performance of SAP by the surgical team, certain reluctance to take up additional paperwork in connection with documentation of SAP as well as the lack of effective incentives to the surgical team introduced by the Management of the Hospital. Regardless of the remarks that can be made in respect of individual aspects of this project, its effective implementation in the clinical practice as well as the achieved economic results convincingly demonstrated the benefits of the interdisciplinary approach in the development and implementation of LG for SAP. The effectiveness of such approach has been also demonstrated in other studies $[27,28,29]$.

\section{CONCLUSIONS}

In order to extend the scope of this project, LG for SAP are planned to be adapted and imple- 
mented in other hospital surgical clinics at the end of this year. Only then conclusions can be drawn about the actual effectiveness and economic viability of LG for SAP at hospital level.

\section{Conflict of Interest Statement}

The authors certify that there are no potential conflicts of interest.

\section{REFERENCES}

1. Kirkland KB, Briggs JP, Trivette SL, Wilkinson WE, Sexton DJ. The Impact of surgical site infections in the 1990's: attributable mortality, excess length of hospitalization, and extra costs. Infect Control Hosp Epidem. 1999; 20:725-30.

2. Weber WP, Zwahlen M, Reck S, Feder-Mengus C, Misteli $\mathrm{H}$, Rosenthal R, et al. Economic burden of surgical site infections at a European university hospital. Infect Control Hosp Epidemiol. 2008; 29(7):623-9.

3. Coello R, Charlett A, Wilson J, Ward V, Pearson A, Borriello P. Adverse impact of surgical site infections in English hospitals. J Hosp Infect. 2005; 60:93-103.

4. Mahmoud NN, Turpin RS, Yang G, Saunders WB. Impact of surgical site infections on length of stay and costs in selected colorectal procedures. Surg Infect (Larchmt). 2009; 10(6):539-44.

5. Surgical Site Infection (SSI) Event. Available from: www.cdc.gov/nhsn/PDFs/pscManual/9pscSSIcurrent.pdf.

6. Konishi T, Watanabe T, Kishimoto J, Nagawa H. Elective colon and rectal surgery differ in risk factors for wound infection. Ann Surg. 2006; 244:758-63.

7. Edwards JR, Peterson KD, Andrus ML, Dudek MA, Pollock DA, Horan TC; National Healthcare Safety Network Facilities. National Healthcare Safety Network (NHSN) Report, data summary for 2006 through 2007, issued November 2008. Am J Infect Control. 2008; 36(9):609-26.

8. Fishman N. Antimicrobial stewardship. Am J Infect Control. 2006; 34(5 Suppl 1):S55-63.

9. Burke JP. Maximizing appropriate antibiotic prophylaxis for surgical patients: an update from LDS Hospital, Salt Lake City. Clin Infect Dis. 2001; 33(Suppl 2):78-83.

10. Burke JF. The effective period of preventive antibiotic action in experimental incisions and dermal lesions. Surgery. 1961; 50:161-8.

11. Polk HC, Lopez-Mayor JE. Postoperative wound infection: a prospective study of determinant factors and prevention. Surgery. 1969; 66:97103.

12. Stone HH, Hooper CA, Kolb LD, Geheber CE, Dawkins EJ. Antibiotic prophylaxis in gastric, biliary and colonic surgery. Ann Surg. 1976; 184:443-52.

13. SIGN Antibiotic Prophylaxis in Surgery. A national Guideline, 2008. Available at www.sign.ac.uk.
14. Iskra Guidelines on Antimicrobial Prophylaxis in Surgery - Croatian National Guideline; 2007.

15. Mangram AJ, Horan TC, Pearson ML, Silver LC, Jarvis WR. Guideline for Prevention of Surgical Site Infection, 1999. Centers for Disease Control and Prevention (CDC) Hospital Infection Control Practices Advisory Committee. Am J Infect Control. 1999; 27:97-132.

16. Derllinger EP, Gross PA, Barrett TL, Krause PJ, Martone WJ, McGowan JE, et al. Quality standard for antimicrobial prophylaxis in surgical procedures. The Infectious Diseases Society of America. Infect Control Hosp Epidemiol. 1994; 15:182-8.

17. ASHP Therapeutic Guidelines on Antimicrobial Prophylaxis in Surgery. Am J Health Syst Pharm. 1999; 56(18):1839-88.

18. National Collaborating Centre for Women's and Children's Health (UK). Surgical Site Infection: Prevention and Treatment of Surgical Site Infection. London: RCOG Press; 2008 Oct. (NICE Clinical Guidelines, No. 74.) Available from: http://www.ncbi.nlm.nih.gov/books/NBK53731/.

19. Dettenkofer M, Forster DH, Ebner W, Gastmeier P, Rüden H, Daschner FD. The practice of perioperative antibiotic prophylaxis in eight German hospitals. Infection. 2002; 30(3):164-7.

20. Burnett KM, Scott MG, Kearney PM, Humphreys WG, McMillen RM. The identification of barriers preventing the successful implementation of a surgical prophylaxis protocol. Pharm World Sci. 2002; 24(5):182-7.

21. Van Kasteren MEE, Kullberg BJ, de Boer AS, Mintjes-de Groot J, Gyssens IC. Adherence to local hospital guidelines for surgical antimicrobial prophylaxis: a multicenter audit in Dutch hospitals. J Antimicrob Chemother. 2003; 51:1389-96.

22. Hosoglu S, Sunbul M, Erol S, Altindis M, Caylan R, Demirdag K, et al. A national survey of surgical antibiotic prophylaxis in Turkey. Infect Control Hosp Epidemiol. 2003; 24(10):758-61.

23. WHO Global Strategy for Containment of Antimicrobial Resistance, Chapter 3: Hospitals. Geneva: World Health Organization; 2001.

24. http://www.whocc.no/atc_ddd_index/

25. Antibiotic Consumption Calculator-ABC Calc. Available from: http://www.escmid.org/ research_projects/study_groups/esgap/abc_ calc/.

26. Bull AL, Russo PL, Friedman ND, Bennett NJ, Boardman CJ, Richards MJ. Compliance with surgical antibiotic prophylaxis- reporting from a statewide surveillance programme in Victoria, Australia. J Hosp Infect. 2006; 63:140-7.

27. Webb ALB, Flagg RL, Fink AS. Reducing surgical site infections through a multidisciplinary computerized process for preoperative prophylactic antibiotic administration. Am J Surg. 2006; 192:663-8.

28. Tonev D, Viachki I, larumov N, Viachki D, Hadzieva $\mathrm{N}$, Vlahov V. Current antibiotic prophylaxis in colorectal surgery. Khirurgiia (Sofia). 1997; 50(6):54-8.

29. Tonev D, Viachki I, Vlahov V. Perioperative antibiotic prophylaxis in abdominal operationsclinical and pharmacoeconomic results. Modern Medicine (Sofia). 1999; 50(5):14-20. 


\title{
Interdisciplinarni pristup razvoju i primeni domaćeg vodiča za hiruršku antimikrobnu profilaksu: iskustvo Univerzitetske bolnice „Carica Joana - ISUL“, u Sofiji, u Bugarskoj
}

\author{
Andrey Petrov ${ }^{1}$, Emil Gatchev ${ }^{1}$, Damyan Damyanov², Boyko Korukov², Emil Kolev ${ }^{1}$ \\ ${ }^{1}$ Medicinski univerzitet u Sofiji, Katedra za kliničku farmakologiju i terapiju, \\ Univerzitetska bolnica „Carica Joana - ISUL“, Sofija, Bugarska; \\ ${ }^{2}$ Medicinski univerzitet u Sofiji, Centar za gastroenterologiju, Hirurška klinika, \\ Univerzitetska bolnica „Carica Joana - ISUL“, Sofija, Bugarska
}

\section{KRATAK SADRŽAJ}

Cilj rada Hirurška antimikrobna profilaksa (HAP) je metoda za koju je dokazano da je efikasna u smanjenju rizika od nastanka infekcije operacionog mesta. Mada postoje brojni međunarodni i domaći vodiči, ova profilaksa se često primenjuje na neodgovarajući način. Nadzor koji je izvršen na Hirurškoj klinici Univerzitetske bolnice „Carica Joana - ISUL“ u avgustu 2008. godine pokazao je da je nivo neadekvatne primene ove profilakse veoma visok. Da bi se našlo najbolje rešenje za HAP, napravljen je domaći vodič za hiruršku antimikrobnu profilaksu.

Metode rada Domaći vodič za hiruršku antimikrobnu profilaksu napravljen je i primenjuje se putem interdisciplinarnog pristupa, na osnovu međunarodno priznatih standarda za HAP, a uzimajući u obzir specifičnost same bolnice. Vršeno je mesečno praćenje nivoa primene HAP u skladu sa domaćim vodičem za HAP. Podneti su izveštaji o primeni antimikrobnih agensa (AMA) na Klinici primenom metode DDD/10o bolesničkih dana.

Rezultati Tri meseca posle primene domaćeg vodiča stopa adekvatno izvedene HAP smanjila se od $5 \%$ do $40 \%$, a na kraju 2009. godine čak i do $92 \%$. Primena AMA u 2009. smanjena je za skoro $26 \%$ : od ukupno 58,71 DDD/100 bolesničkih dana u 2008. godini do 43,45 DDD/100 bolesničkih dana, a ukupni troškovi za AMA smanjeni su za više od 31\%: od 29.764 evra u 2008. do 20.300 evra u 2009. godini.

Zaključak Interdisciplinarni pristup razvoju i primeni domaćeg vodiča za HAP doveo je do optimizacije HAP na Hirurškoj klinici, značajno redukovane primene AMA i znatne finansijske uštede.

Ključne reči: antibiotici; hirurgija 